\title{
Composition and Density of Marine Debris in the Mangrove Ecosystems of the Sungai Rawa Village, Sungai Apit Subsdistrict, Siak Regency, Riau Province
}

\author{
Nurul Fajriah ${ }^{1 *}$, Muhammad Fauzi ${ }^{2}$, Eni Sumiarsih ${ }^{2}$ \\ ${ }^{1}$ Student of The Faculty of Fisheries And Marine Science University of Riau, Pekanbaru \\ ${ }^{2}$ Lecturer at the Faculty Of Fisheries And Marine Science University Riau, Pekanbaru \\ *nurulfajriah936@gmail.com
}

\begin{abstract}
Marine debris is a type of pollutant that commonly found in the mangrove ecosystems. A research aims to determine the composition and density of marine debris in the mangrove ecosystem of the Sungai Rawa Village was conducted in June - July 2018. A survey method was used in this study. Samplings were done three times (once / 2 weeks) at 3 stations namely S1 (ecotourism area), S2 (natural mangrove forest) and S3 (port area and settlement area). Marine debris were collected from 3 plots $(10 \times 10 \mathrm{~m})$ placed along the transect line. The type of marine debris found in the mangrove ecosystem consists of plastic, glass, rubber, fabric, styrofoam, nets, cans, wood, steel and paper. The density of marine debris based on its characteristics are: megadebris $\left(0.01-0.04\right.$ items $/ \mathrm{m}^{2} ; 4.61-34.67$ grams $\left./ \mathrm{m}^{2}\right)$, macrodebris $\left(1.43-4.75\right.$ items $/ \mathrm{m}^{2} ; 249.19-724.53$ grams $\left./ \mathrm{m}^{2}\right)$, mesodebris $(0.79$ - 2.20 items $/ \mathrm{m}^{2} ; 1.54-3.23$ grams $\left./ \mathrm{m}^{2}\right)$. The most common marine debris found is plastic $(69.27 \%)$ and styrofoam $(15.65 \%)$.
\end{abstract}

Keywords: megadebris, macrodebris, mesodebris, styrofoam, plastic remains

\section{PENDAHULUAN}

Wilayah pesisir mempunyai sumber daya alam yang berlimpah khususnya padang lamun, rumput laut, terumbu karang dan mangrove. Sehingga banyak dimanfaatkan oleh masyarakat wilayah pesisir sebagai tempat mencari makan, sarana transportasi dan pelabuhan, kawasan industri, agroindustri, objek pariwisata, kawasan pemukiman.

Banyaknya aktifitas di wilayah pesisir menimbulkan sampah laut (marine debris) yang terakumulasi ke kawasan mangrove. Marine debris merupakan masalah besar, bukan hanya di Indonesia, tetapi di seluruh dunia. Menurut Ryan et al., (2009) menemukan bahwa plastik dan jumlah marine debris di pantai Afrika Selatan meningkat selama 21 tahun sekitar 100600\% (1984-2005). Sedangkan
NOAA (2013) mendeskripsikan marine debris sebagai benda padat persistent, diproduksi atau diproses oleh manusia, secara langsung atau tidak langsung, sengaja atau tidak sengaja, dibuang atau ditinggalkan di dalam lingkungan laut. Tipe marine debris di antaranya plastik, kain, busa, styrofoam, kaca, keramik, logam, kertas, karet dan kayu. Kategori ukuran yang digunakan untuk mengklasifikasikan marine debris, yaitu megadebris $(>1 \mathrm{~m})$, makrodebris $(>2,5 \mathrm{~cm}$ $-1 \mathrm{~m})$, dan mesodebris ( $>5 \mathrm{~mm}-<2,5 \mathrm{~cm})$. Marine debris dapat berdampak pada ekologi laut dan ekonomi masyarakat. Dampak ekologi yaitu terganggunya kehidupan biota laut serta kerusakan ekosistem mangrove. Sedangkan dampak 
ekonomi yaitu menurunnya estetika di lingkungan pesisir, sehingga berkurangnya parawisatawan untuk berkunjung ke objek wisata mangrove. Selain itu, menurunnya ekonomi pada berbagai industri yang bergantung pada lingkungan pesisir dan laut (Bergman, 2015).

Kampung Sungai Rawa Kecamatan Sungai Apit Kabupaten Siak merupakan daerah yang terdapat berbagai aktivitas yaitu pemukiman, aktivitas nelayan, objek wisata dan sebagai jalur transportasi. Aktivitas - aktivitas tersebut dapat memberikan kontribusi pencemaran pada ekosistem mangrove. Selain itu, marine debris juga dapat masuk ke pesisir melalui Sungai Siak, dari aliran Danau Zambrud, Muara Sungai Rawa aliran dan dari perairan laut.

Pencemaran marine debris menjadi masalah utama pencemaran pesisir, namun informasi mengenai pencemaran marine debris di ekosistem mangrove masih relatif sedikit. Permasalahan marine debris yang ada belum menjadi perhatian dalam menentukan strategi pengelolaan pada ekosistem mangrove. Komposisi dan kepadatan sampah laut (marine debris) di ekosistem mangrove merupakan informasi kuantitatif dalam menentukan strategi pengelolaan marine debrisi di Kampung Sungai Rawa Kecamatan Sungai Apit Kabupaten Siak Provinsi Riau.

Penelitian ini bertujuan untuk mengetahui komposisi dari kepadatan jenis dan bobot sampah laut (marine debris) yang tersebar di ekosistem mangrove Kampung Sungai Rawa Kecamatan SungaiApit Kabupaten Siak Provinsi Riau.

\section{METODE PENELITIAN} Waktu dan Tempat

Penelitian ini akan dilaksanakan pada bulan Juni - Juli 2018 di Ekosistem Mangrove Kampung Sungai Rawa Kecamatan Sungai Apit Kabupaten Siak Provinsi Riau. Identifikasi sampel sampah laut (marine debris) langsung dilakukan di lokasi penelitian (sampel diukur dan timbang bobot sampah berdasarkan pembagian jenis sampel). Sedangkan analisis sampel marine debris dilakukan di Laboratorium Ekologi Manajemen Lingkungan Fakultas Perikanan dan Kelautan Universitas Riau.

\section{Alat dan Bahan}

Tali rapiah, meteran atau rol meter, label dan alat tulis, kamera, Global Positioning System (GPS), sarung tangan, mistar besi, layang layang arus, kompas bidik, stopwatch, timbangan dan kantong plastik.

\section{Metode}

Metode yang digunakan dalam penelitian ini adalah metode survei, dimana pengamatan dan pengambilan terhadap sampah laut menggunakan transek garis.

\section{Pengambilan Marine Debris}

Pengambilan marine debris memperhatikan batas jangkauan pangambilan marine debris misalnya daerah jauh jangkauan daerah mangrove ke batas pantai, sehingga pada lokasi penelitian akan dilakukan pengambilan sampah dengan cara penetapan transek garis (line transect) dengan panjang transek $50 \mathrm{~m}$ dengan pembagian 25 meter dari tepi pantai dan 25 meter dari bagian darat wilayah ekosistem mangrove dengan ukuran kuadran yaitu 10 x 10 m sedangkan jarak antar stasiun $\pm 100 \mathrm{~m}$.

Pengambilan sampel marine debris dilakukan 3 kali dalam interval waktu 2 minggu sekali dengan membuat 3 titik kuadran di setiap stasiun /transek pada kawasan mangrove. Hal ini dilakukan untuk melihat pengaruh arus surut dan pasang dalam membawa marine debris keluar dari pesisir maupun masuk ke pesisir dan kawasan mangrove Kampung Sungai Rawa. 
Tahapan Pengambilan Marine debris

- Setelah pengumpulan marine debris, maka sampel tersebut di cuci bersih dengan air.

- dikeringkan menggunakan sinar matahari langsung.

- dilakukan pemisahan bedasarkan karakteristik ukuran marine debris yaitu megadebris, makrodebris dan mesodebris (Lippiat et al., 2013).

- Sampel tersebut dimasukkan ke dalam karung diberi label.

- dihitung dan ditimbang dengan menggunakan portable electronic scale (timbangan gantung).

- Setelah itu dilakukan analisis perhitungan kepadatan jenis (item $/ \mathrm{m}^{2}$ ) dan kepadatan bobot $\left(\mathrm{gram} / \mathrm{m}^{2}\right)$.

\section{Analisis Data Statistik Marine debris}

Persamaan yang digunakan dalam menganalisis data statistik marine debris yaitu kepadatan jenis bedasarkan jumlah perpotongan (item $\left./ \mathrm{m}^{2}\right)$ dan kepadatan bobot bedasarkan berat timbangan $\left(\mathrm{gram} / \mathrm{m}^{2}\right.$ ) marine debris (Coe dan Rogers, 1997 dalam Peters dan Flaherty, 2011) :

1. Kepadatan Jenis Marine debris (item $/ \mathrm{m}^{2}$ )

$=\underline{\text { Potongan marine debris (item) }}$

$$
\text { Luas area }\left(\mathrm{m}^{2}\right)
$$

2. Kepadatan Bobot Marine debris $\left(\mathrm{gram} / \mathrm{m}^{2}\right)$

$=\underline{\text { Berat marine debris (gram) }}$

Luas area $\left(\mathrm{m}^{2}\right)$

\section{Pengukuran dan Analisis Parameter Oseanografi Fisika \\ Pengukuran Arah}

Pengukuran arah dilakukan dengan menggunakan layang-layang arus sebanyak 2 kali pada saat pasang tertinggi dan surut terendah. Layang-layang arus dibiarkan terbawa arus hingga tali lurus, setelah itu mencatat waktu tempuh sepanjang 10 meter dan di bidik dengan menggunakan kompas searah dengan tali untuk menentukan arah arus.

\section{Kecepatan Arus}

Pengambilan kecepatan arus juga dilakukan dengan menggunakan layanglayang arus di masing-masing plot.

$$
\mathbf{V}=\mathbf{s} / \mathbf{t}
$$

\section{Keterangan :}

$\mathrm{V}=$ Kecepatan arus (m/detik)

$\mathrm{s}=$ Jarak tempuh layang-layang arus (m)

$\mathrm{t}=$ Waktu yang digunakan (detik)

\section{Analisis Data}

Data yang diperoleh selama penelitian baik berupa data komposisi dan kepadatan marine debris serta analisis parameter oseanografi dianalis disajikan dalam bentuk tabel dan grafik.

\section{HASIL DAN PEMBAHASAN}

\section{Komposisi dan Kepadatan Bedasarkan Jenis-jenis Marine Debris}

Jenis - jenis marine debris yang terdapat pada lantai permukaan substrat mangrove Kampung Sungai Rawa terdiri dari marine debris organik dan anorganik (Tabel 1). Kepadatan jenis marine debris banyak ditemukan di Stasiun III dibandingkan dengan lokasi stasiun lainnya di Kampung Sungai Rawa yaitu sebesar 6,990 item $/ \mathrm{m}^{2}$. Penyebab marine debris banyak ditemukan di Stasiun III ialah karena banyaknya masyarakat Kampung Sungai Rawa membuang marine debris anorganik berupa plastik, stryofoam dan sebagainya ke pantai, sehingga marine debris yang tadinya berada di tepi pantai saat pasang naik terbawa dan terangkut oleh arus dan angin laut, kemudian dibawa kembali marine debris tersebut dari laut menuju daerah pantai. Hal ini sesuai dengan pendapat NOAA, (2016) bahwa marine debris berasal dari kegiatan di darat dan di laut, marine debris dapat terdistribusi jauh dari sumbernya oleh 
adanya angin dan arus, arus laut merupakan salah satu pendukung perpindahan debris diperairan.

\section{Kepadatan Jenis Marine Debris}

Pada penelitian ini total kepadatan jenis ditemukan di ekosistem Kampung Sungai Rawa sebanyak 12,756 item $/ \mathrm{m}^{2}$, dimana marine debris yang didapatkan selama penelitian berkisar antara 2,221 6,990 item $/ \mathrm{m}^{2}$. Total kepadatan jenis tertinggi terdapat pada Stasiun III sekitar 6,990 item $/ \mathrm{m}^{2}$, sementara nilai kepadatan jenis terendah terdapat pada Stasiun II sekitar 2,221 item $/ \mathrm{m}^{2}$. Jenis-jenis marine debris yang paling banyak ditemukan di ekosistem mangrove ini terdiri dari : plastik 8,786 item $/ \mathrm{m}^{2}$, stryofoam 2,077 item $/ \mathrm{m}^{2}$, logam kaleng 0,666 item $/ \mathrm{m}^{2}$, kaca 0,474 item $/ \mathrm{m}^{2}$, kayu 0,383 item $/ \mathrm{m}^{2}$ dan paling sedikit ditemukan adalah bangkai $\mathrm{kapal} /$ perahu $0,020 \mathrm{item} / \mathrm{m}^{2}$ (Tabel 1)

Tabel 1. Kepadatan Jenis (item $/ \mathrm{m}^{2}$ ) Marine Debris di Setiap Lokasi Penelitian

\begin{tabular}{rlcccc}
\hline No & Jenis Marine debris & I & II & III & $\begin{array}{c}\text { Total Debris } \\
\text { Perjenis }\end{array}$ \\
\cline { 2 - 4 } 1 & Plastik & 2,348 & 1,614 & 4,823 & 8,786 \\
2 & Kaca & 0,176 & 0,041 & 0,258 & 0,474 \\
3 & Pakaian & 0,003 & 0,003 & 0,017 & 0,023 \\
4 & Stryofoam & 0,646 & 0,270 & 1,161 & 2,077 \\
5 & Jaring & 0,007 & 0,007 & 0,019 & 0,032 \\
6 & logam kaleng & 0,206 & 0,070 & 0,390 & 0,666 \\
7 & Kertas & 0,036 & 0,023 & 0,080 & 0,139 \\
8 & Besi & 0,010 & 0 & 0,021 & 0,031 \\
9 & bangkai kapal & 0 & 0 & 0,020 & 0,020 \\
10 & Karet & 0,033 & 0,010 & 0,081 & 0,124 \\
11 & Kayu & 0,081 & 0,182 & 0,120 & 0,383 \\
\hline \multicolumn{2}{r}{ Total } & $\mathbf{3 , 5 4 4}$ & $\mathbf{2 , 2 2 1}$ & $\mathbf{6 , 9 9 0}$ & $\mathbf{1 2 , 7 5 6}$ \\
\hline
\end{tabular}

Tingginya kepadatan jenis marine debris di Stasiun III sebagian besar berupa marine debris berukuran megadebris, makrodebris dan mesodebris yang diduga berasal dari aktivitas manusia. Hal ini karena stasiun tersebut merupakan daerah yang dekat dengan lokasi pemukiman, area pelabuhan kapal dan dekat dengan perairan laut lepas. Marine debris yang terperangkap di ekosistem mangrove juga diduga berasal dari darat, karena berbatasan langsung dengan aktivitas manusia dan pemukiman Kampung Sungai Rawa. Marine debris yang berlimpah di ekosistem mangrove berasal dari aktivitas manusia di darat, limbah industri, aktivitas penangkapan dari laut dan aliran sungai. Hal tersebut juga disampaikan oleh Stevenson (2011), bahwa marine debris berasal dari dua sumber utama, yaitu debris yang dibuang dari aktivitas penangkapan laut dan debris dari darat melalui aliran sungai. Marine debris yang berasal dari darat terdiri atas tiga sumber utama, yaitu industri, pengelolaan derbis yang tidak teratur, dan kebiasaan masyarakat membuang debris sembarangan.

Kebanyakan masyarakat Kampung Sungai Rawa membuang debris anorganik berupa plastik, stryofoam dan sebagainya ketepi pantai, sehingga debris yang tadinya berada ditepi pantai saat pasang naik mudah terbawa angin dan arus laut, pernyataan ini sesuai dengan pendapat NOAA (2016) yang menyatakan bahwa marine debris berasal dari kegiatan di darat dan di laut serta dapat terdistribusi jauh dari sumbernya oleh adanya angin dan 
arus, arus merupakan salah satu faktor yang mendukung perpindahan marine debris diperairan yang akhirnya akan terakumulasi di bibir pantai.

Banyaknya marine debris di Stasiun III disebabkan karena adanya pengaruh oseanografi dari kekuatan angin. Angin di Stasiun III diduga lebih cepat dibandingkan stasiun lainnya karena tidak terhalang oleh pulau buatan. Hal ini menjadi salah satu faktor marine debris mudah ditransportasikan ke dalam ekosistem mangrove. Menurut Kaladharan et al., (2004) membuktikan bahwa jumlah debris di pantai berkorelasi signifikan dengan kecepatan angin, namun tidak berkorelasi dengan arah angin.

Kepadatan jenis marine debris terendah terdapat pada Stasiun II Stasiun II berada dekat dengan Muara Sungai Rawa, marine debris yang terperangkap di Stasiun II memiliki ukuran besar sehingga bobotnya tinggi meskipun jumlah potongnya rendah. Hal ini diduga karena kerapatan pohon Sonneratia alba di Stasiun II tertinggi dibandingkan stasiun lainnya dan tekstur sedimen Stasiun II terendah dibandingkan stasiun lainnya. Marine debris berasal dari kegiatan di darat dan di laut serta dapat terdistribusi jauh dari sumbernya oleh adanya angin dan arus (NOAA, 2013).

Proses pasang surut serta aktivitas manusia dalam membuang debris berperan besar dalam menimbulkan pencemaran dan peningkatan volume marine debris di ekosistem mangrove, hal tersebut terlihat dari keberadaan debris di kawasan mangrove Kampung Sungai Rawa. Marine debris domestik seperti lembaran plastik, kantung plastik, stryofoam, tali, kaleng logam dan lain-lain dapat menjadi masalah karena menutupi area penanaman sehingga anakan mangrove tidak dapat tumbuh sempurna, bahkan dapat menyebabkan semai yang perakarannya masih lemah ikut terhanyut ke laut, hal ini sesuai dengan pendapat Setyawan dan Winarno (2006) bahwa banyaknya debris domestik di kawasan mangrove dapat merusak tumbuh kembangnya perakaran mangrove.

Perbedaan nilai kepadatan jenis marine debris antar stasiun disebabkan oleh jarak stasiun dari laut, hal ini mempengaruhi nilai kepadatan jenis marine debris. Hal ini sama dengan pernyataan Lattin et al., (2004) yang mengatakan bahwa jarak mempengaruhi kepadatan jenis marine debris karena semakin jauh dari sumber pencemaran debris maka jumlah potong dan kepadatan jenis marine debris semakin rendah. Selain itu, perbedaan jumlah marine debris di kawasan ekosistem mangrove Kampung Sungai Rawa juga disebabkan karena banjir saat musim hujan. Saat banjir limbah domestik akan terbawa hingga batas mangrove terdalam. Hal tersebut sesuai dengan pernyataan Costa et al., (2011) bahwa kepadatan jenis marine debris di kawasan mangrove lebih tinggi saat musim hujan dibandingkan musim kemarau. Hal berbeda dilaporkan oleh Ivar do Sul dan Costa (2013) bahwa marine debris di pantai lebih tinggi saat musim hujan.

Bedasarkan persentase marine debris yang di temukan di ekosistem mangrove Kampung Sungai Rawa berkisar 0,10 $69,27 \%$. Marine debris yang paling banyak ditemukan adalah plastik $(69,27 \%)$ dan styrofoam (15,65\%) (Gambar 1). 

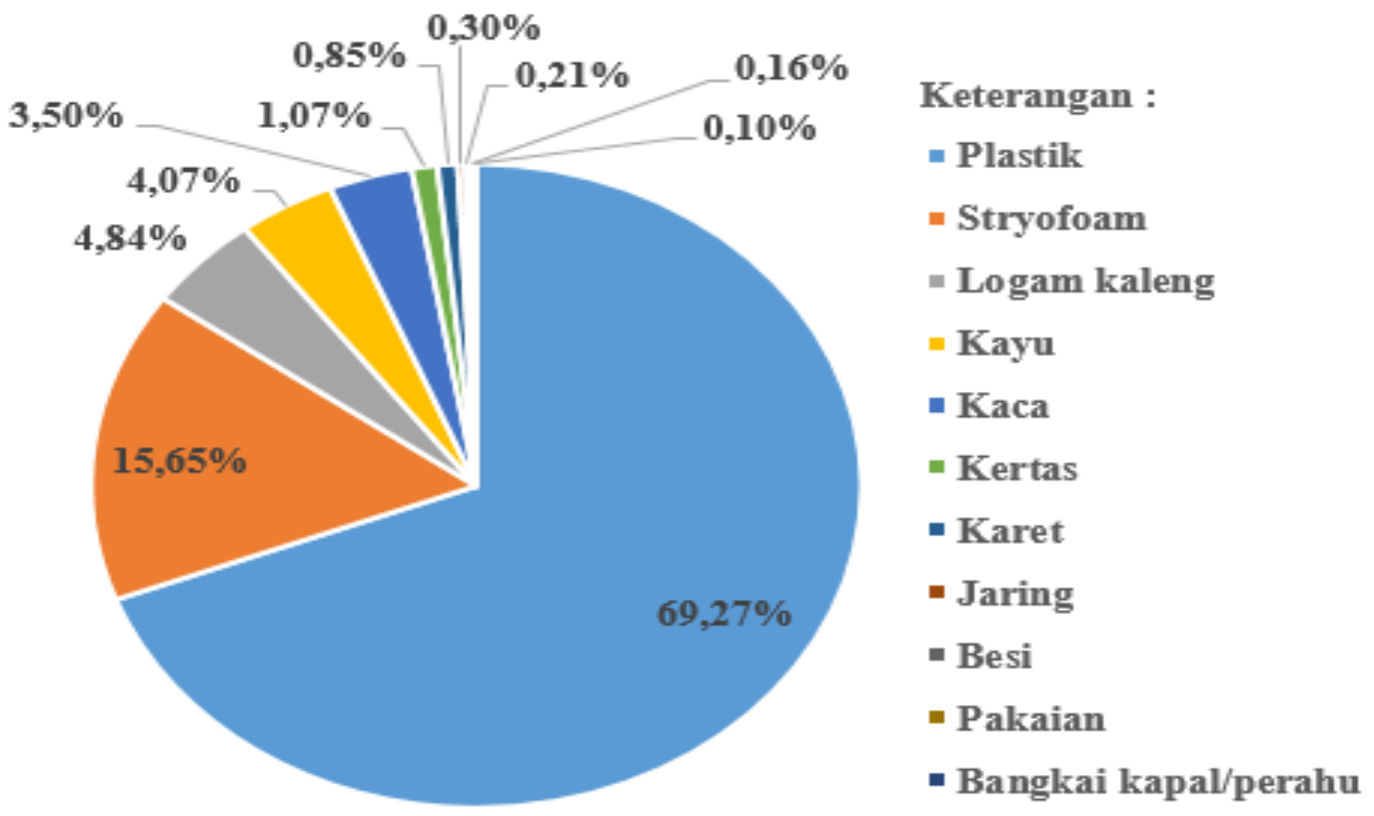

Gambar 1. Persentase Marine Debris di Ekosistem Mangrove Desa Sungai Rawa.

Pada Gambar 1 terlihat jelas bahwa persentase dari potongan plastik lebih tinggi dari marine debris lainnya yaitu $69,27 \%$ dan stryofoam menduduki peringkat kedua sebesar $15,65 \%$. Hal ini sesuai dengan pernyataan Hastuti, (2014) bahwa persentase dari jumlah potong terbanyak adalah plastik (77.7\%) dan styrofoam (18.1\%) di ekosistem mangrove Indah Kapuk Jakarta. Pernyataan yang sama juga disebutkan oleh Costa et al. (2011) bahwa persentase dari jumlah potongan plastik di sedimen mangrove Northeast Coast Brazil sebesar $70 \%$. Sedangkan menurut Santos et al. (2009) menemukan komposisi marine debris terbesar kedua adalah styrofoam sebesar $14 \%$.

Pada kawasan ekosistem mangrove Kampung Sungai Rawa, kepadatan jenis dan persentase marine debris anorganik yang banyak ditemukan adalah plastik. Marine debris dari jenis plastik sangat berbahaya bagi kehidupan organisme laut maupun organisme yang hidup di ekosistem mangrove. Hal ini sesuai dengan pernyataan NOAA (2016) bahwa plastik merupakan jenis yang paling umum dan banyak dijumpai serta yang paling berisiko memberikan dampak terhadap organisme laut. Plastik dan turunan lain dari limbah plastik yang terdapat di laut berbahaya untuk satwa liar dan perikanan. Organisme perairan dapat terancam akibat terbelit, sesak napas, maupun termakan. Hal ini sangat membahayakan lumba-lumba, penyu, hiu, dugong, burung laut, kepiting, dan makhluk lainnya. Plastik yang membelit membatasi gerakan, menyebabkan luka dan infeksi, dan menghalangi hewan yang perlu untuk kembali ke permukaan untuk bernapas.

Selain plastik dan stryofoam yang menjadi sumber terbanyak di ekosistem Mangrove Kampung Sungai Rawa. Jenis marine debris organik dari kayu juga banyak ditemukan di ekosistem mangrove yang berasal dari limbah kayu industri. Jenis marine debris berupa kayu juga ditemukan oleh Hermawan, (2017) marine debris organik di Pulau selayar didominasi oleh kayu yang berukuran besar.

Pada Tabel 1 dapat dilihat kepadatan jenis kayu banyak terdapat pada Stasiun II $0,182 \mathrm{item} / \mathrm{m}^{2}$ yang diduga karena lokasi tersebut berada dekat dengan muara yang 
landai dikelilingi oleh dinding penahan abrasi (seawall), sehingga banyak marine debris organik dari tumpukan kayu-kayu yang berasal dari limbah industri berukuran makrodebris terdampar didaerah tersebut. Hal ini juga disebabkan karena adanya arus. Arus air laut di Stasiun III cenderung lebih kencang dari pada arus di Stasiun I, sehingga marine debris organik di Stasiun II lebih banyak berukuran makrodebris karena dibawa oleh arus dari Stasiun III. Menurut Critchell et al. (2015) juga Critchell dan Lambrechts (2016) pola angin dan pola arus sangat mempengaruhi distribusi marine debris. Angin mempengaruhi pola arus permukaan yang membawa material marine debris terapung mengikuti pola arus permukaan (Choy dan Drazen 2013; Vikas dan Dwarakish, 2015).

\section{Kepadatan Bobot Marine Debris}

Total Kepadatan bobot marine debris yang ditemukan di ekosistem mangrove Kampung Sungai Rawa yaitu 1.620,07 gram $/ \mathrm{m}^{2}$. Kepadatan bobot tertinggi terdapat pada Stasiun III yaitu 762,42 gram $/ \mathrm{m}^{2}$ dan kepadatan bobot terendah terdapat pada Stasiun I yaitu 265,11 gram $/ \mathrm{m}^{2}$. Jenis marine debris kayu menduduki nilai kepadatan bobot tertinggi yaitu $1.146,83 \mathrm{gram} / \mathrm{m}^{2}$, kemudian dengan plastik 259,10 gram $/ \mathrm{m}^{2}$, logam kaleng $64,46 \mathrm{gram} / \mathrm{m}^{2}$, karet $34,51 \mathrm{gram} / \mathrm{m}^{2}$ dan besi $34 \mathrm{gram} / \mathrm{m}^{2}$. Sementara kepadatan bobot marine debris terendah adalah stryofoam sebanyak 5,74 gram $/ \mathrm{m}^{2}$ (Tabel 2)

Tabel 2. Kepadatan Bobot $\left(\mathrm{gram} / \mathrm{m}^{2}\right)$ Marine debris di Setiap Lokasi Stasiun

\begin{tabular}{|c|c|c|c|c|c|}
\hline \multirow{2}{*}{ No } & \multirow[t]{2}{*}{ Jenis Marine debris } & I & II & III & \multirow{2}{*}{$\begin{array}{c}\text { Total Bobot } \\
\text { Perjenis }\end{array}$} \\
\hline & & \multicolumn{3}{|c|}{$\operatorname{gram} / \mathbf{m}^{2}$} & \\
\hline 1 & Plastik & 65,36 & 27,97 & 165,77 & 259,10 \\
\hline 2 & Kaca & 5,51 & 2,00 & 10,32 & 17,84 \\
\hline 3 & Pakaian & 1,00 & 1,06 & 5,17 & 7,22 \\
\hline 4 & Stryofoam & 1,46 & 0,64 & 3,64 & 5,74 \\
\hline 5 & Jaring & 8,72 & 5,72 & 17,29 & 31,73 \\
\hline 6 & logam kaleng & 20,58 & 5,73 & 38,14 & 64,46 \\
\hline 7 & Kertas & 4,89 & 1,59 & 11,83 & 18,31 \\
\hline 8 & Besi & 6,72 & 0 & 27,61 & 34,33 \\
\hline 9 & Karet & 3,88 & 1,50 & 29,13 & 34,51 \\
\hline 10 & Kayu & 147,00 & 546,32 & 453,51 & $1.146,83$ \\
\hline & Total & 265,11 & 592,53 & 762,42 & $1.620,07$ \\
\hline
\end{tabular}

Tingginya kepadatan bobot marine debris di stasiun III disebabkan karena pada lokasi tersebut terdapat banyak marine debris anorganik dan organik yang terakumulasi di tepi pantai mangrove yang berasal dari aktivitas manusia. Tingginya marine debris di Stasiun III disebabkan juga karena pergerakan arus yang mengakibatkan marine debris anorganik maupun organik dapat berpindah dan terbawa arus ke satu tempat ke tempat lainnya. Hal ini sesuai dengan pendapat
Zulkarnaen (2017), bahwa perpindahan marine debris dapat terjadi karena arus pada saat pasang bergerak menuju ekosistem mangrove dan dapat terakumulasi di daerah mangrove.

Kepadatan bobot pada Stasiun I cenderung rendah. Hal ini disebabkan karena lokasi Stasiun I dekat dengan aliran Sungai Rawa, selain berasal dari aliran sungai sampah laut juga berasal dari perairan laut lepas yang disebabkan oleh adanya pasang surut. Selain itu, tingginya kerapatan pohon mangrove Rhizophora 
mucronata di Stasiun I yang menyebabkan nilai kepadatan bobot marine debris menjadi rendah. Pernyataan yang sama juga disebutkan oleh Hastuti (2014) bahwa tingginya kerapatan pohon mangrove dapat mengurangi kepadatan bobot marine debris.

\section{Parameter Oseanografi}

Data oseanografi yang didapatkan dari kecepatan arus menggunakan layanglayang arus konvensional pada saat pasang maupun surut dapat dilihat pada Tabel 3 berikut

Tabel 3. Kecepatan dan Arah Arus di Setiap Lokasi Stasiun

\begin{tabular}{ccccc}
\hline \multirow{2}{*}{ Stasiun } & \multicolumn{2}{c}{ Pasang } & \multicolumn{2}{c}{ Surut } \\
\cline { 2 - 5 } & Arus (m/s) & Arah & Arus (m/s) & Arah \\
\hline I & 0,01 & Tidak beraturan & 0,02 & Tidak beraturan \\
II & 0,05 & Selatan & 0,07 & Utara \\
III & 0,06 & Selatan & 0,07 & Utara \\
\hline
\end{tabular}

Nilai kecepatan rata-rata di 3 titik lokasi penelitian yang semuanya masuk dalam kategori arus lambat. Pada lokasi Stasiun I merupakan lokasi penelitian yang pergerakan arus paling lambat jika dibandingkan dengan 2 lokasi pengamatan. Pada saat pasang rata-rata nilai kecepatan Stasiun I adalah $0,01 \mathrm{~m} / \mathrm{s}$ dan pada saat surut sekitar $0,02 \mathrm{~m} / \mathrm{s}$. Hal tersebut diduga karena di lokasi ini terdapat breakwater (pemecah ombak), hal ini sebanding dengan yang dikatakan oleh FAO (2013) yang menyebutkan bahwa breakwater berfungsi mengurangi kecepatan arus dan tinggi rambatan gelombang, sehingga hal tersebut dapat mempengaruhi laju pergerakan air yang ditimbulkan.

Sedangkan Stasiun II merupakan lokasi penelitian yang berkecepatan arusnya paling cepat dengan rata-rata nilai kecepatan arus berkisar $0,05 \mathrm{~m} / \mathrm{s}$ pada saat pasang dan $0,07 \mathrm{~m} / \mathrm{s}$ pada saat surut. Kondisi ini disebabkan karena Stasiun II merupakan lokasi yang secara langsung berhadapan dengan laut lepas begitupun dengan Stasiun III.

Arah arus yang diperoleh di tiga Stasiun pada saat pasang cenderung mengarah ke selatan, sedangkan pada saat surut cendrung ke arah utara. Sehingga dapat diasumsikan bahwa sampah terakumulasi di lokasi penelitian datang dari arah selatan dan menuju ke utara, kemudian pada saat surut sampah tersebut diduga terbawa oleh arus kembali ke arah selatan. Hal ini sesuai dengan pengelompokkan yang ditentukan oleh Mason (1981) dalam Fajar (2016) bahwa nilai untuk pergerakan air yang berarus sangat cepat $(>1 \mathrm{~m} / \mathrm{s})$, sedang $(0,25-0,5$ $\mathrm{m} / \mathrm{s})$, lambat $(0,01-0,25 \mathrm{~m} / \mathrm{s})$ dan sangat lambat $(<0,01 \mathrm{~m} / \mathrm{s})$.

\section{Pengelolaan Sampah Laut}

Adapun cara pengelolaan sampah laut yang dapat dilakukan di ekositem mangrove Kampung Sungai Rawa adalah sebagai berikut :
a. Memberikan edukasi kepada masyarakat yaitu dengan menyadarkan masyarakat pesisir akan pentingnya menjaga kelestarian kawasan mangrove.
b. Mengubah perilaku masyarakat sehingga semakin sedikit dalam menghasilkan sampah laut.
c. Membuat beberapa titik TPS (tempat pembuangan sampah) pada setiap kawasan mangrove.


d. Daur ulang, mengumpulkan sampah laut yang memiliki nilai eksotik atau unik dan dibersihkan sehingga menarik sebagai pajangan seperti botol-botol antik, kerajinan kayu menjadi furnitur dan lain sebagainya. Sampah laut yang bisa dijual adalah plastik yang tebal dan berat, seperti: keranjang plastik, pelampung, jeriken plastik, dan lainnya.

e. Penggunaan kembali sampah laut, untuk menunjang kebutuhan seharihari. misalnya dalam merakit bubu ikan atau perangkap kepiting. Menggunakan langsung sampah laut, seperti pagar kebun dengan kayu dan bambu dari sampah laut, botol plastik untuk wadah atau pelampung rumput laut dan jaring ikan.

f. Penggunaan sampah laut sebagai bahan bakar.

g. Menggunakan sampah laut sebagai kayu bakar untuk dapur rumah tangga.

h. Mengurangi sampah laut di sekitar mangrove dengan cara dibakar.

Partisipasi masyarakat sangat penting dalam sebuah keberlanjutan suatu pengelolaan (Walalangi, 2012).

\section{KESIMPULAN DAN SARAN}

\section{Kesimpulan}

Komposisi marine debris yang ditemukan pada ekosistem mangrove Kampung Sungai Rawa terdiri dari limbah kayu industri, karet (sandal atau sepatu karet dan ban mobil bekas), styrofoam, kaleng logam, kaca (botol kaca dan bohlam lampu); plastik (botol plastik, gelas plastik, tali dan jaring plastik, korek gas, keranjang plastik, pelampung, pembungkus makanan, sikat gigi dan spuit) besi, bangkai kapal/perahu, jaring ikan dan pakaian.

Kepadatan marine debris banyak ditemukan di Stasiun III sekitar 6,990 item $/ \mathrm{m}^{2}$ dan bobot $762,42 \mathrm{gram} / \mathrm{m}^{2}$, dimana jenis marine debris yang banyak ditemukan di ekositem mangrove adalah plastik $(69,27 \%)$ dan Styrofoam $(15,65 \%)$.

\section{Saran}

Peran pemerintah daerah perlu didorong dalam mengelola sampah laut yang lebih baik lagi khususnya dikawasan ekosistem mangrove Kampung Sungai Rawa Kecamatan Sungai Apit Kabupaten Siak Provinsi Riau.

\section{DAFTAR PUSTAKA}

1. Coe, J.M. and Rogers, D.B. 1997. Marine Debris: Sources, Impacts, and Solutions. Spinger-Verlag New York. Hal : 439

2. Choy, C and Drazen, J. 2013. Plastic for dinner Observations of frequent debris ingestion by pelagic predatory fishes from the central North Pacific. Marine Ecology Progress Series. Vol. 485 : 155-163

3. Costa, M.F. Silva, C.J.S, Barbosa, C.C. Portugal, J.L. and Barletta, M. 2011. Plastics buried in the inter-tidal plain of a tropical Journal of Coastal Research. (64) : 339-343.

4. Fajar, M. 2016. Identifikasi Sampah Laut di Kawasan Wisata Pantai Makasar. Skripsi. Fakultas Ilmu Kelautan dan Perikanan. Universitas Hasanuddin. 72 hal.

5. [FAO]. Food and Agriculture Organization. 2013. Fishing Harbour Planning, Construction and Management: Breakwater. Summary. www.FAO.org_[diakses 13 oktober 2018] 
6. Hastuti, A.R. 2014. Distribusi Spasial Sampah Laut di Ekosistem Mangrove Pantai Indah Kapuk Jakarta. Skripsi. Departemen Manajemen Sumber Daya Perairan Fakultas Perikanan dan Ilmu Kelautan. Insitut Pertanian Bogor. Bogor. 41 hal.

7. Hermawan, R. 2017. Analisis Jenis dan Bobot Sampah Laut di Pesisir Barat Pulau Selayar Sulawesi Selatan. Tesis. Program Studi Pengelolaan Sumberdaya Pesisir dan Lautan, Insitut Pertanian Bogor. Bogor. 81 hal

8. Ivar, S.J.A and Costa, M.F. 2013. Plastic pollution risks in an estuarine conservation unit. Journal of Coastal Research. (65) : 48-53.

9. Kaladharan, P. Prema, D. Nandakumar, A. and Valsala, K.K. 2004. Occurrence of tarball and waste materials on the beaches along Kerala coast in India. Journal of the Marine Biological Association of India. 46 (1) : 93-97.

10. Lattin, G.L. Moore, C.J. Zellers, A.F. Moore, S.L. And Weisberg, S.B. 2004. A comparison of neustonic plastic and zooplankton at different depths near the southern California shore. Marine Pollution Bulletin. (49) : 291-294.

11. Lippiat, S. Opfer, S. and Arthur, C. 2012. Marine Debris and Monitoring Assesment. NOAA. 82 hal.

12. [NOAA]. National Oceanic and Atmospheric Administration. 2013. Programmatic Environmental Assessment (PEA) for the NOAA Marine Debris Program (MDP). Maryland (US. $168 \mathrm{Hal}$.

13. 2015. Turning The Tide On Trash. A Learning Guide On Marine Debris. NOAA PIFSC CRED.

14. Peters, K. and Flaherty, T. 2011. Marine Debris in Gulf Saint Vincent Bioregion. Adelaide (AU): Government of South Australia. Hal : 19.

15. Ryan, P.G. Moore, C.J. Franeker, J.A. and Moloney, C.L. 2009. Monitoring the abundance of plastic debris in the marine environment. Philosophical Transactions of the Royal Society. (364) :1999 - 2012.

16. Setyawan, A.D. dan K. Winarno. 2006. Permasalahan Konservasi Ekosistem Mangrove di Pesisir Kabupaten Rembang, Jawa Tengah. Biodiversitas (7) : 159-163.

17. Stevenson, C. 2011. Plastic Debris in the Calofornia Marine Ecosystem. A Summary of Current Research, Solution Strategies and Data Gaps. University of Southern California Sea Grant. Synthetic Report. California Ocean Science Trust, Oakland, CA. 70 hal.

18. Walalangi, J.Y. 2012. Analisis Komposisi Sampah Organik Dan Anorganik Serta Dampak Terhadap Lingkungan Pesisir Kota Palu Sulawesi Tengah. Tesis. Program Studi Pengelolaan Sumberdaya Pesisir dan Lautan, Insitut Pertanian Bogor. Bogor. 112 hal.

19. Zulkarnaen, A. 2017. Identifikasi Sampah Laut (Marine Debris) di Pantai Bodia Kecamatan Galesong, Pantai Karama Kecamatan Galesong Utara, dan Pantai Mandi Kecamatan Galesong Selatan Kabupaten Takalar. Skripsi. Fakultas Ilmu Kelautan dan Perikanan. Universitas Hasanuddin. Makassar. 61 hal. 